\title{
Calcareous Nanofossil of Post-Gondwana Sequence in Southern Banda Arc, Indonesia
}

\author{
Angga Jati Widiatama ${ }^{1 *}$, Lauti Dwita Santy ${ }^{2}$, Rikza Nur Faqih An Nahar ${ }^{1}, Z_{\text {Zulfiah }}^{3}$, Winda \\ Eka Mandiri Puteri ${ }^{3}$, Adrianus Damanik ${ }^{3}$, Rubiyanto Kapid ${ }^{3}$ \\ ${ }^{I}$ Geological Engineering, Institut Teknologi Sumatera, South Lampung, 35365, Indonesia. \\ ${ }^{2}$ Geological Survey Center, Geological Agency, Ministry of Energy and Mineral Resources, Bandung, 40122, Indonesia. \\ ${ }^{3}$ Geological Engineering, Institut Teknologi Bandung, Bandung, 40132, Indonesia.
}

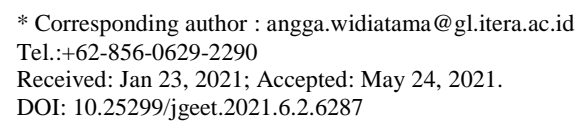

\section{Abstract}

The presence of calcareous nannofossils in samples of the Post-Gondwana sequences (Kolbano and Viqueque sequence) gives guidance about the relative age of the study area located in the Outer Banda Arc, namely Timor, Rote, and Sawu Island. The study was carried out on six traverses, Timor Island traverse (Baun and Camplong), Rote Island traverse (Termanu and Central Rote), and Sawu Island traverses (West Sawu and East Sawu). There is 29 outcrop sample prepared using the smear slide method and observed using a polarizing microscope with 1000x magnification. The results of the study showed the presence of Cretaceous, Paleogene, and Neogen-Quarternary calcareous nannofossil. There are 82 species from 14 families identified in the post-Gondwana sequence. The results showed that the assemblage of calcareous nannofossil in Cretaceous characterized by the presence of Watznaueria fasciata, Watznaueria cynthae, Cyclagelosphaera brezae, Orastrum campanensis, and Micula concava. The assemblage of Paleogene calcareous nannofossil characterized by the presence of Coccolithus staurion, Chiasmolithus solitus, Discoaster minimus, Tawelus (?) magnicrassus, Chiasmolithus bidens, Prinsius africanus, Cyclicargolithus luminus, Spenolithus elongatus, Reticulofenestra umbilica, Cruciplacolithus vanheckae, and Helicospharea seminulum, and the assemblage of Neogene calcareous nannofossil characterized by the presence of Reticulofenestra pseudoumbilica, Discoaster quinqueramus, Helicosphaera princei, and Discoaster pansus. Quarternary calcareous nannofossil characterized by the presence of Ponthospaera indooceanica.

Keywords: Calcareous Nannofossil, Kolbano Sequence, Banda Arc

\section{Introduction}

Timor, Rote, and Sawu Island are located in the outer Banda Arc formed by the collision between the edges of the Australian continent and volcanic Banda Arc (M.G, 2004; Villeneuve et al., 2004). Timor Island and its surrounding area litotectically divided into five major groups (Fig. 1); (1) Gondwana sequences, Permian to Jurassic, containing siliciclastic rocks deposited in the intracratonic basin, (2) Kolbano sequence containing siliciclastic rock and pelagic carbonate from late Jurassic to Neogene, (3) Banda terrain which is part of Asia that has been uplifted due to collision during Late Neogen. (4) Bobonaro Melange contains melange with blocks in clay, broken formation, and mud domes formed during the collision in the late Neogen, (5) Viqueque sequence which is synorogenic deposits which are relatively undeformed (Barber et al., 1977; Carter et al., 1976; Harris et al., 1998; M.G, 2004; Villeneuve et al., 2004). Kolbano sequence contains siliciclastic and pelagic carbonate consisted of the Nakfunu, Menu, Ofu, and Batuputih Formation. While the Viqueque sequence consists of the Viqueque Formation and Quarternary deposits.

The Nakfunu Formation (Sawyer, 2018; Suwitodirjo, 1996) is identical to the Wai Bua Formation in Timor Leste (Audley-Charles, 1968) that the lithology consists of chert, claystone, calcilutite, shale, calcarenite, wackestone, and packstone. One of Nakfunu Formation characteristics is the consistency of layer thickness which ranges from 3 to 30 $\mathrm{cm}$ with sharp contact, flat to wavy. Shale units can be thin or massive layers, black with iron and manganese nodules. Sedimentary structures are rarely found in the Nakfunu Formation except for laminates. The Nakfunu Formation is deposited during marine transgression of Early Cretaceous in the distal continental rise or abyssal near or below the CCD (Sawyer, 2018).

Sawyer et al. (2018) described Menu Formation consisting of Cretaceous rocks from Early to Late Cretaceous which have lithological characteristics in the form of red-pink to white calcilutite limestone layers. Some layers are pelecypods wackestone, layered between 6 to 60 $\mathrm{cm}$, the layer is sharp, there are also $1-2 \mathrm{~cm}$ red chert layers with an intensive joint. Menu Formation in Rote Island was exposed in several areas including Baa, Termanu, and Papela.

The dominant lithology of Ofu Formation is white to pink massive limestone concoidal-subconcoidal fractures and looks shiny like porcelain on a fresh surface. There are laminates and intensive pressure solutions resulted in calcite veins in stylolites and fractures. Updated biostratigraphy from existing formations and distinguished three mapped units, Boti, Borolalu, and Oeleu members. The lithology consists of pelecypods-foraminifera wackestone; quartz packstone or foraminifera packstone; and turbidite conglomerates layered with angular fragments from Menu Formation or Ofu Formation. The age of this 
unit is Lutetian phase in the Middle Eocene to the Early Pliocene (Sawyer, 2018).

The Plio-Pleistocene series is aimed for syn-orogenic sediments known as Viqueque Sequence [8] or the Batuputih Formation (Sawyer, 2018; Suwitodirjo, 1996). This includes the equivalent of Viqueque, Batuputih, and Noele Formation in West Timor. The lithology of Batuputih Formation mainly consists of white massive calcilutite or chalky limestone with light grey marl and often with plant fragments. This unit is soft to hard and the layer is less visible. The tuffaceous layer is very rare outside the type location even though vitric glass fragments are often found. Coarse bioclastic and clastic allogens are found in the interlocking parts with Noele Formation.
Viqueque Formation consists of coarsening upward from chalky limestone and calcilutite to sandstones covered by Quaternary gravel and reef limestones. The Viqueque Formation appears in the Central Basin in west and south of the Kolbano unit that was imbricated. The Noele Formation shows lithological variations reflected rapidly uplift and topographic variations in depositional environments. The lithology includes marl, carbonate claystone, tuffaceous marl, tuffaceous calcilutite, white-yellow glass tuffs, biocalcarenite, siltstone, sandy limestone, dark grey marl, and sandstone. As for differences with Batuputih Formation, calcilutite and chalky limestone are rarely found.

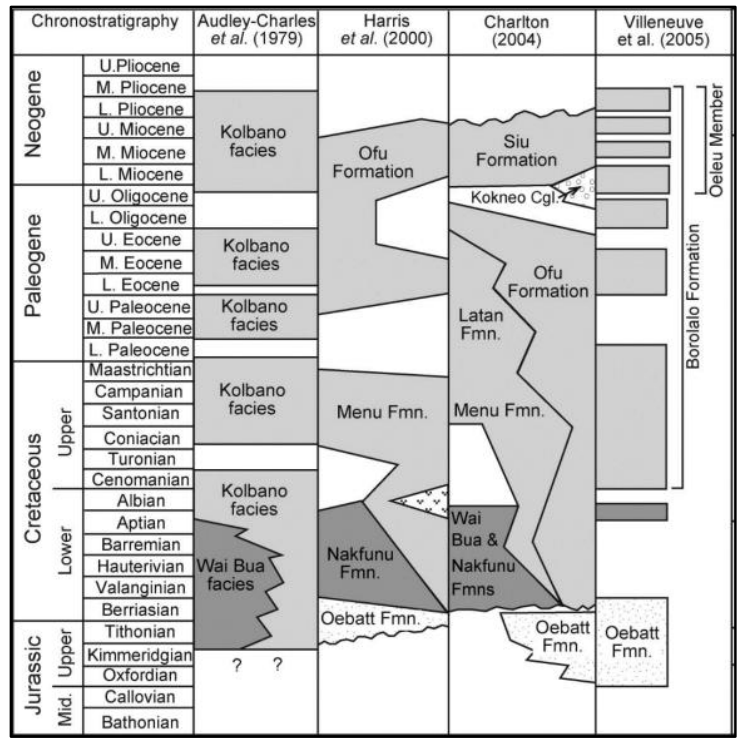

Fig 1. Stratigraphy column of research area from various author

\section{Material and Method}

The objective of this study is identify calcareous nannofossil in post-Gondwana sequences (Kolbano and Viqueque sequence) and to determine the relative age based on calcareous nannofossil in islands around southern Outer Banda Arc. Field data collection carried out in the survey activities of the Sawu basin included three islands, Timor, Rote, and Sawu. The research conduct by the Geological Survey Center, Geological Agency, Ministry of Energy, and Mineral Resources in 2014. The research data including six traverses (Fig. 2) Timor Island Traverse (Baun and Camplong), Rote Island Traverse (Termanu and Central
Rote), and Sawu Island Traverse (West Sawu and East Sawu). Data collection includes stratigraphic measurements, descriptions of megascopic rocks, microscopic descriptions, and paleontology of calcareous fossils.

There are 29 calcareous nanofossil samples prepared by the smear slide method and observed using a polarizing microscope with 1000x magnification. The age determination of Cenozoic calcareous nannofossil based on Martini's zone (Martini, 1970) while the Mesozoic zone based on Bown and Cooper zonation (Bown and Cooper, 1998).

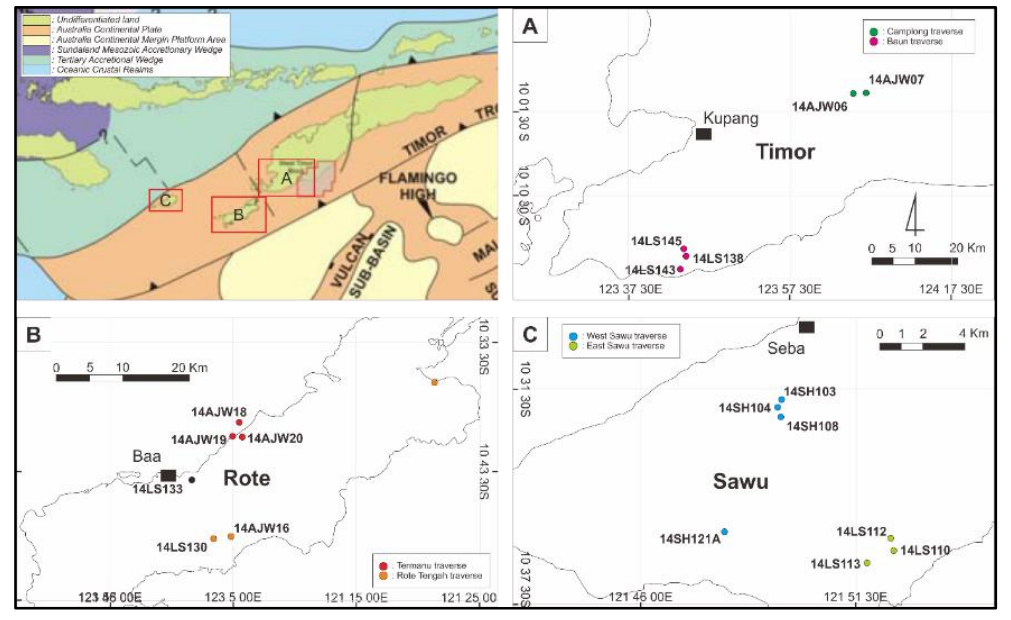

Fig. 2 Map of research area (A) Timor Island Traverse, (B) Rote Island Traverse, and (C) Sawu Island Traverse 


\section{Geology research area}

\subsection{Timor Island}

There are two observation points of Camplong Traverse, 14AJW06, and 14AJW07 (figure 2A). The outcrop is on Trans Timor road near Mina River bridge with a length of 50 meters and a height of 20 meters. Lithology consists of a layering of tuffaceous limestone, chalky limestone, foraminifera grainstone, marl, and conglomerates. The measured section column is shown in figure 4A. The lower part of the outcrop consists of light white tuffaceous-chalky limestone layering, having intensive joint, 20-30 layer thickness, medium compacting with parallel lamination. The age is not older than Burdigalian (NN4) to Tortonian (NN 10), which characterized by the first appearance of the Reticulofenestra pseudoumbilica until the first appearance of Discoaster quinqueramus. The middle section consists of chalky limestone turning into intercalation of foraminifera grainstone-marl with an erosive layer contact (figure 3A). White foraminifera grainstone has medium compacting, bioclastic components, insitu planktonic foraminifera, and rework foraminifera, bivalves, juvenile Mollusca, tuffaceous, with plagioclase and quartz as additional components. Marl dominant forms of carbonate mud with planktonic foraminifera as the main bioclastic. Marl and the foraminifera grainstone have erosional contact.
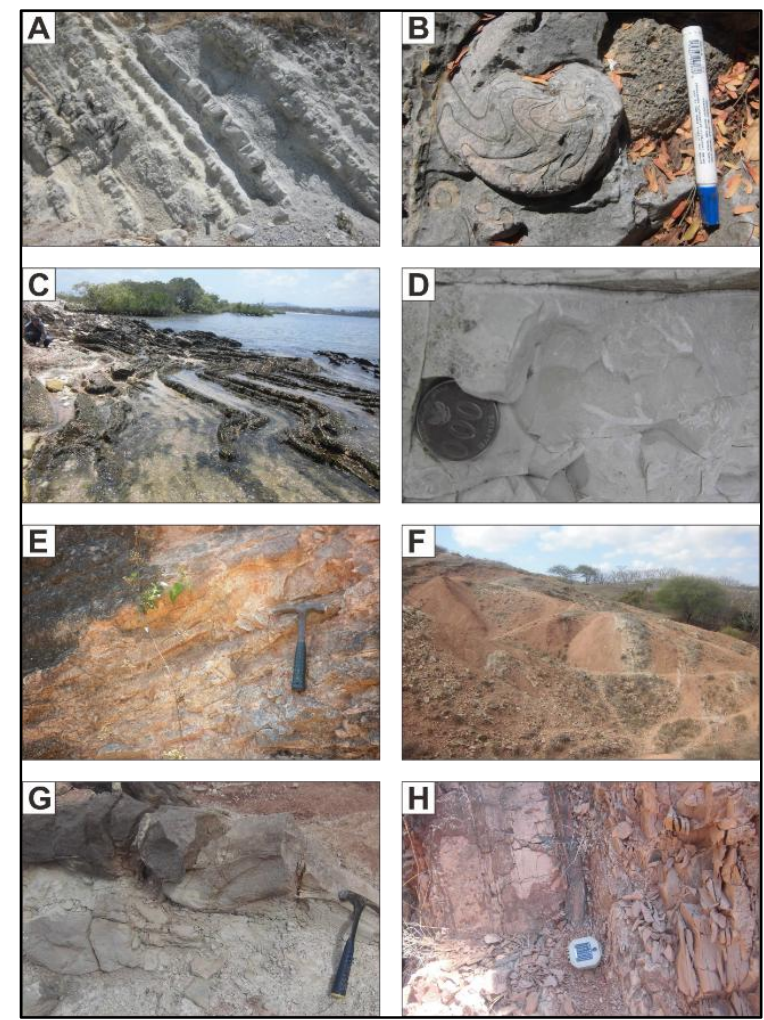

Fig. 3 Post-Gondwana sequence outcrop (A) Intercalation of foraminifera grainstone and marl, (B) Amonite limestone, (C) Calcilutite and chert intercalation, (D) Trace fossils of Chondrites and Planolites in calcilutite, (E) Neogene orange calcilutite in

Rote Island, (f) Paleogene calcilutite in Sawu Island, (G) Layer of foraminifera grainstone with flutecast at the lower part of the layer, and $(\mathrm{H})$ Calcilutite with fissile structure.

Based on calcareous nannofossil foraminifera grainstone is Tortonian-Messinian (NN 11) characterized by the presence of Discoaster quinqueramus. The upper part of the outcrop is an unconformity between foraminifera grainstone -marl intercalation cut by conglomerates with Quarternary matrix. Based on nannofossil on the matrix shown NN20 zone or younger which characterized by the first appearance of Ponthospaera indooceanica.

There are three observation points of Baun Traverse, 14LS138, 14LS143, and 14LS145 (figure 2A) located in Bihati River, Baun is composed of broken formation of ammonite limestone, calcilutite, foraminifera grainstone, and basalt. The measured section columns are shown in figures $4 \mathrm{~A}$ and $4 \mathrm{~B}$. Ammonite limestone (figure $3 \mathrm{~B}$ ) is reddish-white, poorly sorted, high compaction, consists of Ammonite sp., Crinoid sp., Halobia sp., and Atomodesma sp. a distinctive characteristics of Gondwana sequences of Permo-Triassic rocks that have a fault contact with a postGondwana sequence. The Kolbano sequence consists of pale pinkish calcilutite and pale white calcilutite with parallel lamination and firm layer contact. Late Cretaceous nannofossil zone from the Santonian-Campanian (UC 11UC 15) characterized by first the appearance of the Orastrum campanensis and Micula concava in the lower part of the section until the last appearance of Orastrum campanensis in the upper part of measured stratigraphy section. In the upper reaches of Bihati River also found well-lamination of white foraminifera grainstone, consist of 20-30 layer thickness, medium compacting with parallel lamination. Burdigalian-Tortonian age (NN 4-NN 10) characterized by the first appearance of Reticulofenestra pseudoumbilica appearance until the first appearance Discoaster quinqueramus. These units are unconformity overlap of ammonite limestone and calcilutite with fault contact.

\subsection{Rote Island}

Termanu traverse consists of three observation points, 14AJW18, 14AJW19, and 14AJW20 in Tanjung Termanu (figure 2B). The measured section column is shown in figure 4D. Outcrops consist of calcilutite, chert, and marl with radiolaria as the dominant bioclastic component. Limestone is relatively thickening upward, while the chert is relatively thinning upward (figure $3 \mathrm{C}$ ). Based on calcareous nannofossil in the lower part of the Tanjung Termanu section, the age shows Early Cretaceous between Berriasian and Valanginian (NC2 - NC3) is marked by the first appearance of Cyclagelosphaera brezae, Watznaueria fasciata, and Watznaueria cynthae until the last appearance of Cyclagelosphaera brezae. In the central part of the Termanu traverse (14AJW20) above the intersection of calcilutite, chert, and marl, the chert layer tends to become more dominant calcilutite and marl, parallel lamination, consist of ichnofossil such as Chondrites, Planolites, and Zoophycos (figure 3D). The age of rocks is Early Cretaceous, Hauterivian to Aptian (NC5 - NC7) based on the last appearance of Cyclagelosphaera brezae until the last appearance of Watznaueria fasciata. The upper part of the Termanu traverse is Late Cretaceous from Albian to Coniacian (NC 8-UC 10) marked by calcilutite characteristic changes of color from pink to orange. The lower part of this zone is marked by the first appearance of Watznaueria fasciata, the upper part is marked by the first appearance of Orastrum campanensis and Micula concava.

Central Rote Traverse (figure 2B) located in Central Rote (14AJW16, 14LS130, and 14LS133) to Papela Beach (14AJW12). The outcrop on Papela Beach is characterized by calcirudite limestone with unoriented Mollusca shell fragment as the main component and associated with manganese boulder and quartz sandstones. The outcrop consists of a broken formation, surrounded by the scaly clay mélange Bobonaro. The presence of Watznaueria fasciata 
indicates Early Cretaceous between Berriasian and Aptian (NC2-NC7). Outcrops at the observation point 14LS130, 14LS133, and 14AJW16 can be divided into four zones. The lower part (zone 1) consists of red to orange foraminifera grainstone, well layered, $10-20 \mathrm{~cm}$ layer thickness, medium compacting, fissile structure, and parallel lamination, Burdigali-Tortonian age (NN4 - NN 10) marked by the first appearance of the Reticulofenestra pseudoumbilica until the first appearance of Discoaster quinqueramus. The middle zone (zone 2) consists a layer of red to orange calcite limestone (figure $3 \mathrm{E}$ ), with dominant foraminifera bioclastic component. The age shows Tortonian-Messinian age (NN 11) characterized by the first appearance of Helicosphera princei and Discoaster quinqueramus until the last appearance of the Discoaster quinqueramus. Conformable grayish-white grainstone foraminifera (zone 3) overlay zone 2, interspersed with layers of tuffaceous lapilli limestone and plant fragments, with medium compacting, the age indicated MessinianZanclean (NN 12-NN 15) marked by the first appearance of Discoaster pansus until the last appearance of the Discoaster pansus. The upper part (zone 4) is foraminifera limestone with poorly lamination, medium compaction, overlay with foraminifera grainstone. The aged are Pliocene-Pleistocene (NN16 - NN21) characterized by the last appearance of the Discoaster pansus until the last appearance of Dictyococcites productus and Helicosphaera princei. The measured section column is shown in figure $4 \mathrm{C}$.

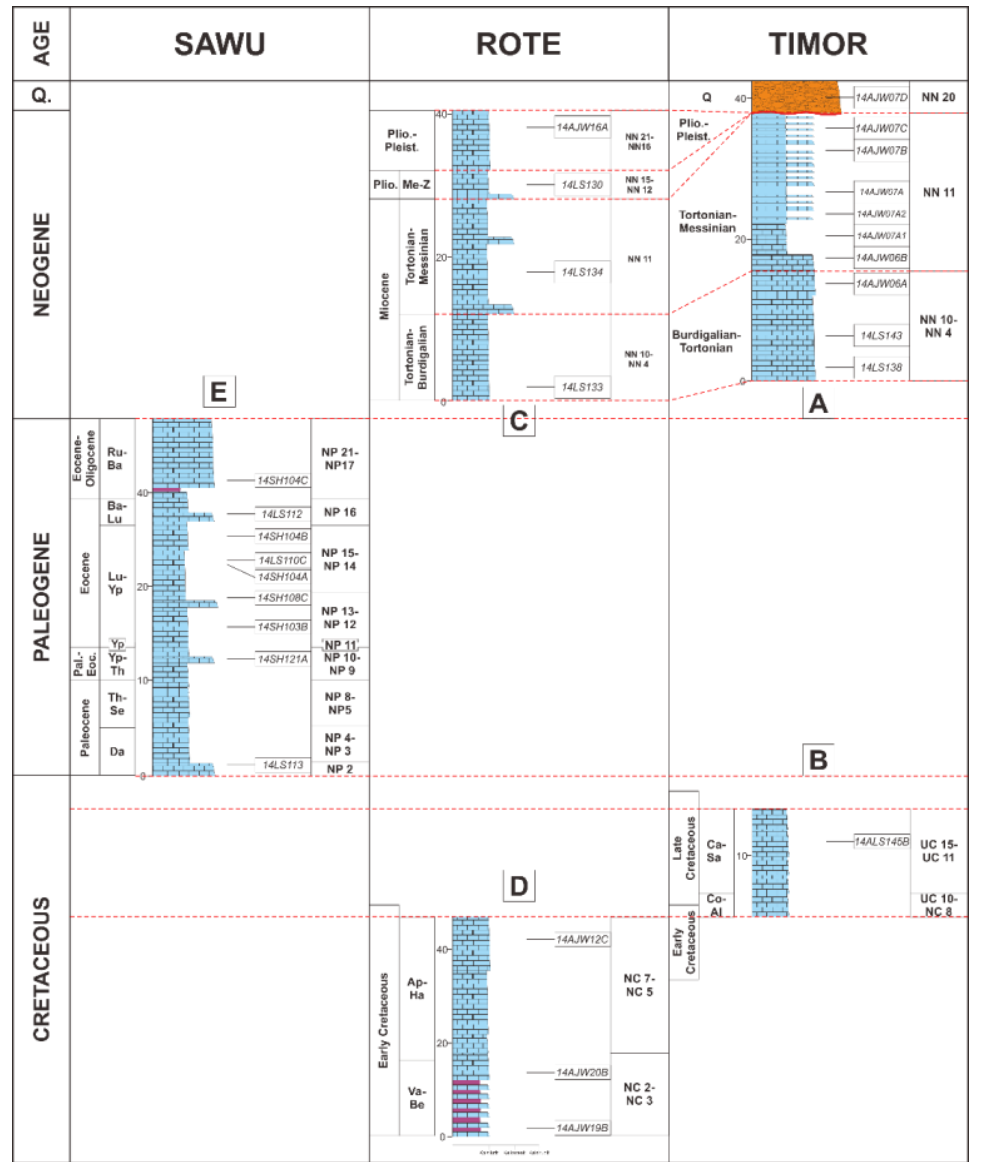

Fig. 4 Measured stratigraphic correlation and biozonation of calcareous nannofossil in Timor Island (A and B), Rote Island (C and D), and Sawu Island (E).

\subsection{Sawu Island}

West Sawu traverse (figure 2C) consists of four observation points (14SH103, 14SH104, 14SH108, and 14SH121). The West Sawu traverse consists of the foraminifera grainstone at the lower part that gradually becomes calcilutite at the top. Foraminifera grainstone is white, dominated by planktonic foraminifera, with minor benthonic foraminifera, erosional contact at some layer, graded bedding, flute cast, forming channel geometry, and lateral thinning layer. The aged are Thanetian (NP9) tagged by the first appearance of Coccolithus staurion and Chiasmolithus solitus to Ypresian (NP11) that labeled by the last appearance of Discoaster minimus and Tawelus (?) magnicrassus. It is also indicated by presence of foraminifera Globigerinatheka sp. As Paleogene marker. Foraminifera grainstone gradually changed to red calcilutite with parallel lamination, $5-15 \mathrm{~cm}$ layer thickness.
Petrographically, calcilutite is a foraminifera wackestone to foraminifera mudstone. The age is from Yalcian (NP11) to Lutetian (NP15) marked by the first appearance of Chiasmolithus bidens until the last appearance of Coccolithus staurion and Cyclicargolithus luminus. The measured section column is shown in figure 4E.

East Sawu Traverse (figure 2C) consists of three observation points (14LS110, 14LS112, and 14LS113). The East Sawu traverse consists of foraminifera grainstone at the lower part gradually becomes calcilutite at the top with implied chert (figure 3F). Foraminifera grainstone characterized by an erosive contact with layer below it, layered $15 \mathrm{~cm}$ in thickness, graded bedding, parallel lamination, flute cast (figure 3G), and forming a channel geometry in lateral. Foraminifera grainstone is Danian (NP2), which is tagged by the presence of Prinsius africanus and also the presence of foraminifera Globigerinatheka sp. as a marker of Paleogene. 
Foraminifera on grainstone originates from foraminifera in situ and rework deposited. On top of foraminifera grainstone gradually turns into red calcilutite, the thin layer of 5-10 cm, with parallel lamination and scaly structures (figure $3 \mathrm{H}$ ). Based on the petrographic observations of calcilutite composed foraminifera wackestone to foraminifera mudstone. Calcilutite indicated Ypersian (NP14) to Lutetian (NP15) based on the presence of Spenolithus elongatus. In the East Sawu travers, limestone characterized by the first appearance of the Reticulofenestra umbilica and the last appearance of Cruciplacolithus vanheckae, Chiasmolithus solitus, and Helicosphaera seminulum indicated age of Middle Eocene (Lutetian to Bartonian/NP16), that overlapped with chert layer with bioclastic component like bivalve shells and radiolaria.

\section{Discussion}

Correlations of measured section columns of Timor, Rote, and Sawu showed in figure 4. The Southern Outer Banda Arc consist of 20 zones of calcareous nanofossil biostratigraphy (figure 5). Gondwana and post-Gondwana sequences are characterized by break-up unconformity that occurs in the Early Cretaceous (Baumgartner, 1993). Calcareous nanofossil of Cretaceous Kolbano sequences consisted of four families and 17 species (Table 1).

The Watznaueriaceae family has the most species diversity with twelve species, Holococcoliths with four species, Family Biscutaceae with one species, and Polycyclolithaceae with only species. Menu Formation aged Early Cretaceous, NC2-NC3 zone with the first appearance of Cyclagelosphaera brezae, Watznaueria fasciata, and Watznaueria cynthae in Berriasian to the last appearance of Cyclagelosphaera brezae in Valanginian. Late Cretaceous (Santonian/UC11) Menu Formation is characterized by the first appearance of Orastrum campanensis and Micula concava. Late Cretaceous nannofossil dominated by the Calculites genus. Cretaceous nanofossil showed in figure 6 .

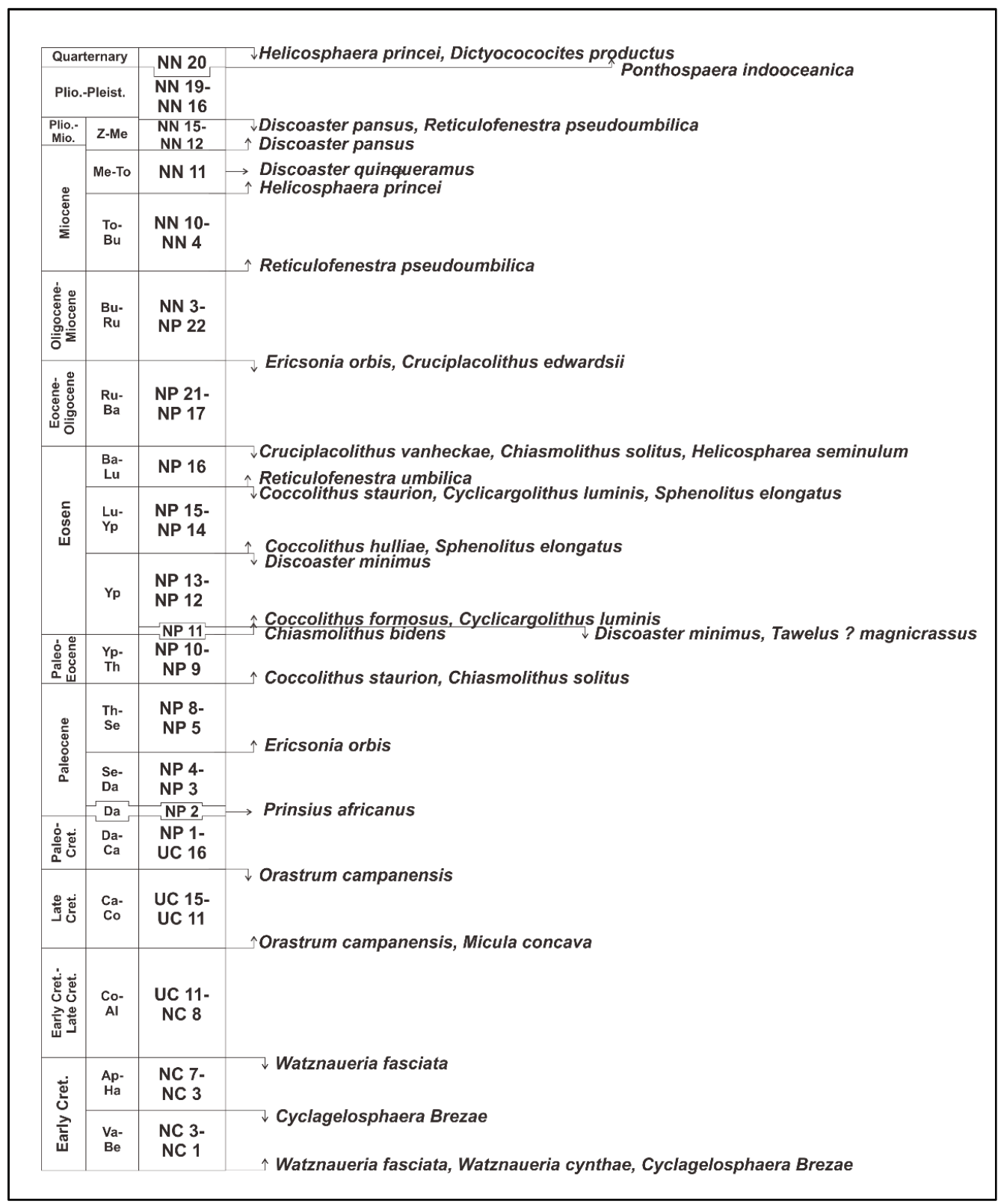

Fig. 5 Biostratigraphy chart of calcareous nannofossil Post-Gondwana sequence in the Banda Arc. 
TABle 1. Diversity OF CRETACEOUS CALCAREOUS NANOFOSSIL

\begin{tabular}{clcl}
\hline No & Calcareous nanofossil & No & Calcareous nanofossil \\
\hline \multirow{2}{*}{1} & Family Biscutaceae & 8 & Cy. deflandrei \\
& Discorhabdus ignotus & 9 & Cy. margerelii \\
& Family Holococcoliths & 10 & Watznaueria \\
2 & Aspigolithus parcus & 11 & Wz. biporta \\
3 & Calculites obscurcus & 12 & Wz. britannica \\
4 & Calculites ovalis & 13 & Wz. cynthae \\
5 & Orastrum campanensis & 14 & Wz. fasciata \\
& Family & 15 & Wz. fossacincta \\
6 & $\begin{array}{l}\text { Polycyclolithaceae } \\
\text { Micula concava }\end{array}$ & 16 & Wz. manivitiae \\
& Family Watznaueriaceae & 17 & Wz. ovata \\
7 & Cyclagelosphaera & & \\
Brezae & & \\
\hline
\end{tabular}

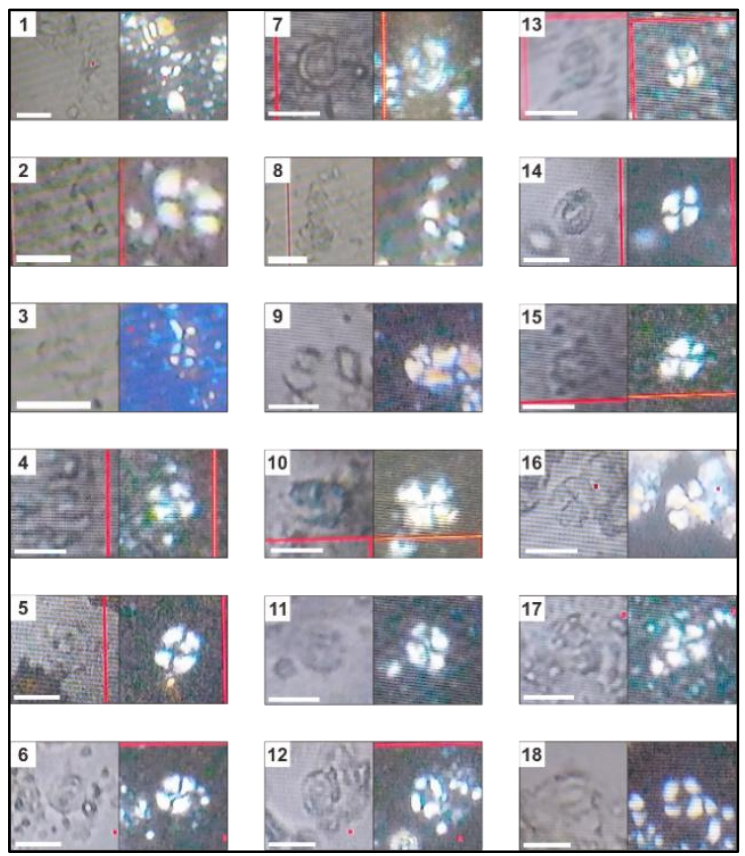

Fig. 6 Cretaceous calcareous nannofossil, scale bar $5 \mu \mathrm{m}$. (1) Aspigolithus parcus; (2) Calculites obscurcus; (3) Calculites ovalis; (4) Cy. Brezae; (5) Cy. deflandrei; (6) Cy. margerelii; (7)

Discorhabdus ignotus; (8) Micula concava; (9) Orastrum campanensis; (10) Wz. barnesiae; (11) Wz. biporta; (12) Wz.

britannica; (13) Wz. cynthae; (14) Wz. fasciata; (15) Wz. fossacincta; (16) Wz. manivitiae; (17) Wz. manivitiae; (18) Wz.ovata.

The Paleocene to Miocene sediment of the Kolbano sequence is grouped in the Ofu Formation, in the form of a graded foraminifera grainstone into calcilutite. Paleogene Calcareous nannofossil of Kolbano sequence consisted of eight families and 31 species (Table 2). Coccolithaceae family has fifteen species, Noelaerhabdaceae as many as three species, Sphenolithaceae has three species, Prinsiaceae composes three species, Pontosphaeraceae as many as two species, Watznaueriaceae consist of two species, Discoasteraceae has two species, and Helicosphaeraceae as many as one species. Prinsius africanus is an index fossil of the Danian (NP2). The beginning of the Eocene started by the appearance of Chiasmolithus bidens (Ypresian / N11). Eocene nannofossils dominated by Coccolithus, Chiasmolitus, and Reticulofenestra genus. The upper limit of the Eocene (Eocene-Oligocene transition) marked by the last appearance of Ericsonia orbis and
Cruciplacolithus edwardsii. Paleogene nannofossil selected showed in figure 7.

Table 2. Diversity Of Paleogene Calcareous Nanofossil

\begin{tabular}{|c|c|c|c|}
\hline No & Calcareous nanofossil & No & $\begin{array}{l}\text { Calcareous } \\
\text { nanofossil }\end{array}$ \\
\hline & Family Coccolithaceae & \multicolumn{2}{|c|}{ Family Helicosphaeraceae } \\
\hline 1 & Chiasmolithus bidens & 19 & H. seminulum \\
\hline 2 & Ch. consuetus & \multicolumn{2}{|c|}{ Family Pontosphaeraceae } \\
\hline 3 & Ch. nitidus & 20 & P. cf. Scisurra \\
\hline 4 & Ch. solitus & 21 & P. diamorphosus \\
\hline 5 & Coccolithus formosus & \multicolumn{2}{|c|}{$\begin{array}{c}\text { Family Sphenolithaceae } \\
\text { Spenolithus cf. }\end{array}$} \\
\hline 6 & Co. hulliae & 22 & spiniger \\
\hline 7 & Co. pauxillus & 23 & S. radians \\
\hline 8 & Co. pelagicus & 24 & S. Elongatus \\
\hline 9 & Co. staurion & \multicolumn{2}{|c|}{ Family Watznaueriaceae } \\
\hline 10 & $\begin{array}{l}\text { Cruciplacolithus } \\
\text { edwardsii }\end{array}$ & 25 & Cy. reinhardtii \\
\hline 11 & Cr. primus & 26 & Cy. luminis \\
\hline 12 & Cr.tenuis & \multicolumn{2}{|c|}{ Family Prinsiaceae } \\
\hline 13 & Cr. vanheckae & 27 & Prinsius africanus \\
\hline 14 & Ericsonia orbis & 28 & $\begin{array}{l}\text { P. tenuiculum } \\
\text { Toweius }\end{array}$ \\
\hline 15 & E. subpertusa & 29 & magnicrassus \\
\hline & $\begin{array}{l}\text { amily Noelaerhabdaceae } \\
\text { Reticulofenestra cf. }\end{array}$ & \multicolumn{2}{|c|}{ Family Discoasteraceae } \\
\hline 16 & ornata & 30 & Discoaster minimus \\
\hline 17 & R. dictyoda & 31 & D. barbadiensis \\
\hline 18 & R. umbilica & & \\
\hline
\end{tabular}

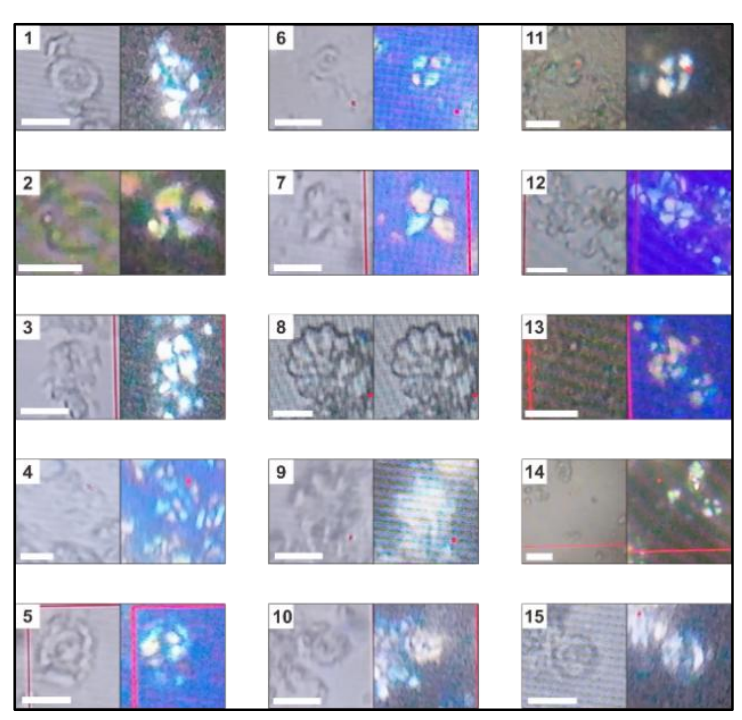

Fig. 7 Paleogene calcareous nannofossil in Sawu Island: (1) Ch. bidens; (2) Ch. solitus; (3) Co. formosus; (4) Co. hulliae; (5) Co. staurion; (6) Cr. edwardsii; (7) Cy. luminis; (8) D. barbadiensis;

(9) D. minimus; (10) E. orbis; (11) H. seminulum; (12) Prinsius africanus; (13) R.umbilica; (14) S. elongatus; and (15) Tawelus(?) magnicrassus. Scale bar $5 \mu \mathrm{m}$.

The Ofu Formation of Kolbano sequence continued until Miocene, that lithology predominantly contained the foraminifera grainstone with the insertion of calcilutite and tuff layers overlay by Viqueque Sequence which age is Quarternary. Neogene-Quarternary calcareous nannofossil in the study area consisted of eight families and 33 species (Table 3). The Discoasteraceae family has the most species diversity with twelve species, Noelaerhabdaceae with ten species, Calcidiscaceae with three species, Helicosphaeraceae with two species, Sphenolithaceae with two species, Coccolithaceae with two species, Pontosphaeraceae with one species, and Nannolith families inc sed with one species. The first appearance of the Reticulofenestra pseudoumbilica becomes the lower boundary of the Miocene age. Miocene nannofossils are 
dominated by Discoaster, Coccolithus, Sphenolithus, and Reticulofenestra genus. The upper Miocene-Pliocene boundary was marked by the first appearance of the Discoaster pansus. Quarternary sediment is marked by the appearance of Ponthospaera indooceanica. Quarternary nanofossil is dominated by the genus Gephyrocapsa. Neogene-Quarternary nannofossil selected is shown in figure 8 .

Integration of sedimentology and paleontology data provides a comprehensive understanding of depositional environments. The calcilutite and chert show that the similarity of the constituent bioclastic in the form of radiolaria showing the relationship between the Menu Formation which is calcilutite dominant and the Nakfunu Formation containing hemipelagic siliciclastic rocks. The similarity of the dominant radiolaria bioclastic component indicates depositional environment is in the upwelling area (Bak, 2007; De Wever et al., 2014, 1994). Upwelling areas provide three conditions that increase the chances of preservation of silica-rich sediment deposits; (1) high nutrition in the upwelling area results in greater productivity of phytoplankton causing silica saturation due to the high productivity of radiolarian-rich deposits, (2) increasing the rate of organic material production below the upwelling zone implying a lower ratio of carbonate shelled organisms, (3) high organic components preventing dissolution of silica (De Wever, 1989; De Wever et al., 1994; 2014)

The correlation among the Central Rote traverse in the form of pelagic Mollusca deposited as turbidite carbonates turned into calcilutite supported by radiolarian on the Termanu traverse indicated a change of depositional facies from slope to the basin floor. Pelagic carbonate deposition continues until the Late Cretaceous is shown to be similar in thickness to the calcilutite facies.

TABLE 3. Diversity of NEOGENE-QUARTERNARY CALCAREOUS NANOFOSSIL

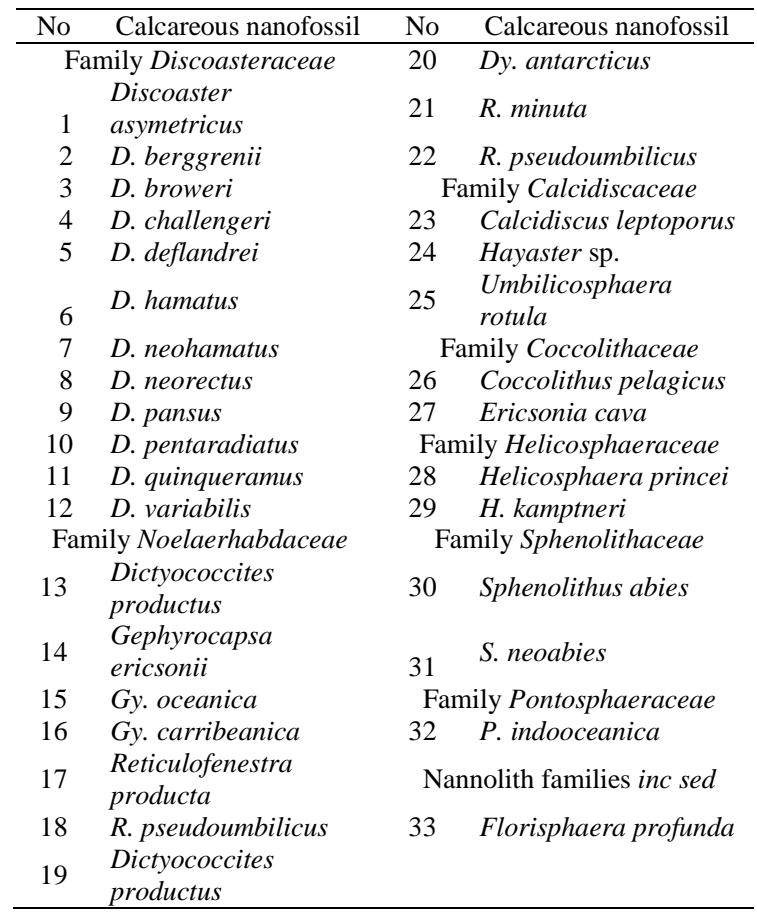

Sedimentary rock of the Ofu Formation in the Paleocene to Eocene show a change in pink and white. The character of the red limestone is identical to the widespread Oceanic Red Bed (ORB) deposit known as the low latency facies type in the Tethys Sea (Cai et al., 2012; $\mathrm{Hu}$ et al., 2005; SCOTT et al., 2009). Red limestone caused by the presence of iron $(\mathrm{Fe} 2+/ \mathrm{Fe} 3+)$. According to Cai et al. (Cai et al., 2012, 2009, 2008) an authigenic hematite formed in calcite crystals is it not only on the surface of the rock but also throughout the limestone. The typical characteristic sediment of Ofu Formation is indicated by the repetition of the deposition sequence in the form of a foraminifera grainstone to calcilutite. Foraminifera grainstone deposited with a turbidite mechanism when decreasing the sea level, while calcilutite deposited during rising sea level to the maximum sea level.

The sedimentary rocks of the Ofu Formation in the Miocene-Pliocene consist of a pink foraminifera grainstone that graded into white at the top. The dominance of the planktonic foraminifera indicates a more depositional environment towards the basin. The intersection of the foraminifera grainstone and marl indicates turbidity current control. The tuff and lapili components indicate the presence of explosive volcanism which become the source of volcaniclastic rocks originate from the Banda Arc.

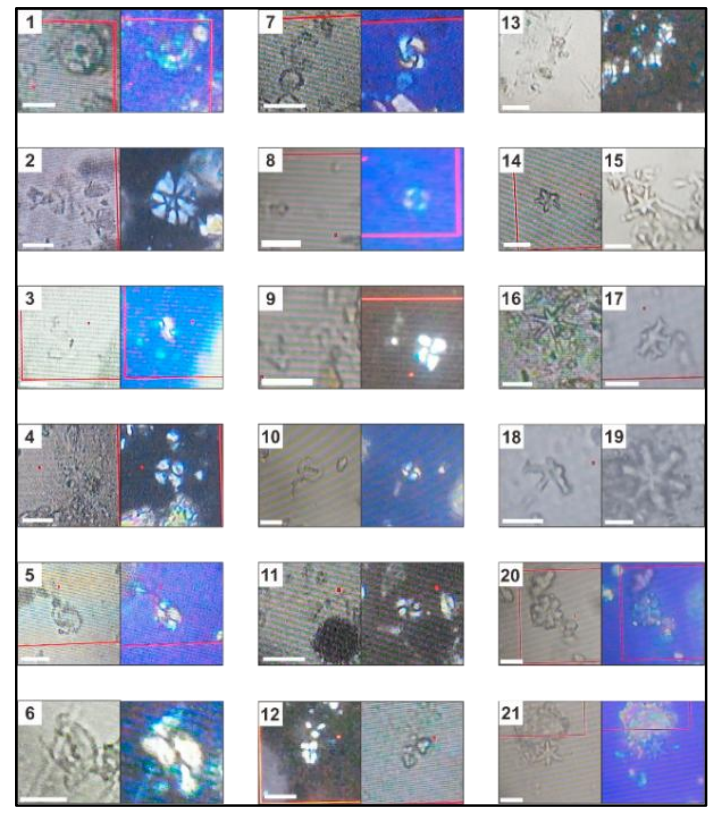

Fig. 8 Neogene-Quarternary calcareous nannofossil in Timor Island, bar $5 \mu \mathrm{m}$.: (1) C. leptoporus; (2) Hayaster sp.; (3) Umbilicosphaera rotula; (4) Co. pelagicus; (5) Helicosphaera kamptneri; (6) H. princei; (7) Dy. productus; (8) Gy. ericsonii; (9) Gy. oceanica; (10) R. producta; (11) R. pseudoumbilicus; (12) S. abies; (13) S. neoabies; (14) D. berggrenii; (15) D. neorectus; (16) D. broweri; (17) D. challengeri; (18) D. quinqueramus; (19) D. variabilis; (20) D. deflandrei; (21) D. neohamatus. Scale

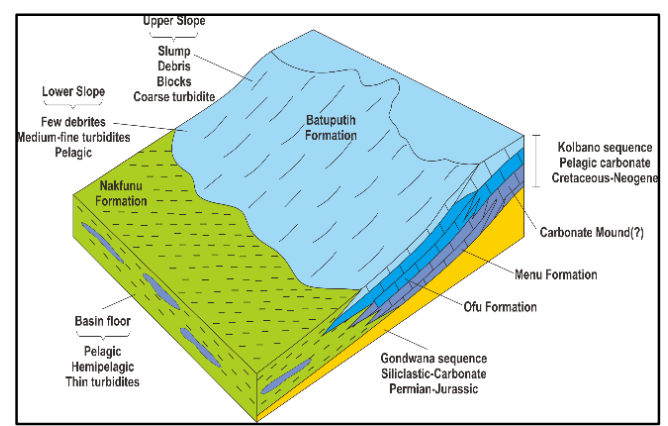

Fig. 9 Depositional environment model of post-Gondwana sequence in research area. 
Pliocene-Quarternary rocks are deposits of the Viqueque sequences that form synorogenic in the collision between Banda Arc and Australian passive margin. Matrix supported Conglomerates indicate formation due to mass flow. The depositional environment model of the study area is illustrated in figure 9 .

\section{Conclusion}

Calcareous nannofossil of Kolbano sequence identified 82 species from 14 families consist of Cretaceous, Paleogene, and Neogen age. The Cretaceous calcareous nannofossil assemblage consists of 18 species (Table 1) dominated by the Watznaueria and Cyclagelosphaera genus. The oldest index nanofossil in the Kolbano sequence is Berriasian based on the first appearance of $C y$. brezae. The Paleogene calcareous nannofossil assemblage consists of 31 species (Table 2) dominated by Pontosphaera, Cruciplacolithus, Chiasmolithus, and Coccolithus genus with index nannofossil is Prinsius africanus, Danian (NP2). The beginning of the Eocene started with the appearance of Chiasmolithus bidens (Ypresian/NP11) and dominated by Coccolithus, Chiasmolitus, and Reticulofenestra genus. The Neogene-Quarternary calcareous nannofossil assemblage consists of 33 species (Table 3 ) dominated by Discoaster, Coccolithus, Sphenolithus, Reticulofenestra, and Gepyrocapsa genus. R. pseudoumbilica becomes the marker of Early Miocene (NN4-NN10), NN11 zone marked by the existence of $D$. quinqueramus and $D$. berggrenii. Quarternary (NN19 zone) characterized by the first appearance of $P$. indooceanica.

\section{Acknowledgements}

We like to thank the Geological Agency, the Indonesian Ministry of Energy and Mineral Resources for lending data, all members of the 2014 Sawu Basin Team who have helped in data collection, and all parties who have made suggestions to make this paper better.

\section{References}

Audley-Charles, M.G., 1968. The Geology of Portuguese TimoAudley-Charles, M. G. (1968): The Geology of Portuguese Timor, Geological Society London Memoirs.

https://doi.org/10.1144/gsl.mem.1968.004.01.02r. Geol. Soc. London Mem.

Bak, K., 2007. Environmental Changes around the Cenomanian-Turonian Boundary in a Marginal Part of the Outer Carpathian Basin Expressed by Microfacies, Microfossils and Chemical Records in the Skole Nappe (Poland). Ann. Soc. Geol. Pol.

Barber, A.J., Audley-Charles, M.G., Carter, D.J., 1977. Thrust tectonics in timor. J. Geol. Soc. Aust. https://doi.org/10.1080/00167617708728966

Baumgartner, P.O., 1993. Early Cretaceous radiolarians of the Northeast Indian Ocean (Leg 123: Sites 765, 766 and DSDP Site 261): The Antarctic-Tethys connection. Mar. Micropaleontol. https://doi.org/10.1016/0377-8398(93)90025-S

Bown, P.R., Cooper, M.K.E., 1998. Jurassic, in: Calcareous Nannofossil Biostratigraphy. https://doi.org/10.1007/978-94-011-4902-0_4

Cai, Y., Hu, X., Li, X., Pan, Y., 2012. Origin of the red colour in a red limestone from the Vispi Quarry section (central Italy): A high-resolution transmission electron microscopy analysis. Cretac. Res. https://doi.org/10.1016/j.cretres.2011.11.016

Cai, Y., Li, X., Hu, X., Chen, X., Pan, Y., 2009.
Paleoclimatic approach to the origin of the coloring of Turonian pelagic limestones from the Vispi Quarry section (Cretaceous, central Italy). Cretac. Res. https://doi.org/10.1016/j.cretres.2009.06.002

Cai, Y., Li, X., Pan, Y., Hu, X., 2008. The color-causing mechanism of Mn\&lt;sup\&gt;2+\&lt;/sup\&gt; and Fe\&lt;sup\&gt;3+\&lt;/sup\&gt;: Evidence from the Italian Cretaceous pelagic red limestones. Acta Geol. Sin.

Carter, D.J., Audley-Charles, M.G., Barber, A.J., 1976. Stratigraphical analysis of island arc-continental margin collision in eastern Indonesia. J. Geol. Soc. London. https://doi.org/10.1144/gsigs.132.2.0179

De Wever, P., 1989. Radiolarians, Radiolarites, and Mesozoic Paleogeography of the CircumMediterranean Alpine Belts, in: Siliceous Deposits of the Tethys and Pacific Regions. https://doi.org/10.1007/978-1-4612-3494-4_3

De Wever, P., Azema, J., Fourcade, E., 1994. Radiolaires et radiolarites: production primaire, diagenese et paleogeographie. Bull. - Centres Rech. Explor. Elf Aquitaine.

De Wever, P., O’Dogherty, L., Goričan, Š., 2014. Monsoon as a cause of radiolarite in the Tethyan realm. Comptes Rendus - Geosci. https://doi.org/10.1016/j.crte.2014.10.001

Harris, R.A., Sawyer, R.K., Audley-Charles, M.G., 1998. Collisional melange development: geologic associations of active melange-forming processes with exhumed melange facies in the western Banda orogen, Indonesia. Tectonics. https://doi.org/10.1029/97TC03083

Hu, X., Jansa, L., Wang, C., Sarti, M., Bak, K., Wagreich, M., Michalik, J., Soták, J., 2005. Upper Cretaceous oceanic red beds (CORBs) in the Tethys: Occurrences, lithofacies, age, and environments. Cretac. https://doi.org/10.1016/j.cretres.2004.11.011

M.G, A.-C., 2004. Ocean trench blocked and obliterated by Banda forearc collision with Australian proximal continental slope. Tectonophysics.

Martini, E., 1970. Standard palaeogene calcareous nannoplankton zonation. Nature. https://doi.org/10.1038/226560a0

Sawyer, R.K., 2018. The stratigraphy and sedimentology of West Timor, Indonesia. https://doi.org/10.29118/ipa.207.533.574

SCOTT, R.W., HU, X., WANG, C., WAGREICH, M., JANSA, L., 2009. Introduction to Cretaceous Oceanic Red Beds: Stratigraphy, Composition, Origins, and Paleoceanographic and Paleoclimatic Significance. Cretac. Ocean Redbeds 7-10. https://doi.org/10.2110/sepmsp.091.007

Suwitodirjo, T., 1996. Peta Geologi Lembar Kupang Atambua, Timor, Pusat Penelitian dan Pengembangan Geologi.

Villeneuve, M., Cornée, J.-J., Martini, R., Zaninetti, L., 2004. New hypothesis on the origin of the Timor Island formations (South East Asia) | Nouvelle hypothèse sur l'origine des formations géologiques de l'île de Timor (Sud-Est asiatique). Comptes Rendus

Geosci. https://doi.org/10.1016/j.crte.2004.09.011

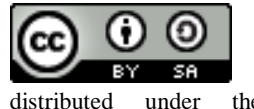

(C) 2021 Journal of Geoscience, Engineering, Environment and Technology. All rights reserved. This is an open access article under the terms of the CC BY-SA License (http://creativecommons.org/licenses/by-sa/4.0/). 